\title{
Development of "Third Places" Function of Transitional Library in the New Campus of Universities
}

\author{
Qi Lihong \\ Library \\ Yangtze University \\ Wuhan, China \\ qilihong928@sina.com
}

\begin{abstract}
The aim of this study was to develop the function of "third places" in the transition Library of the new campus of university. On the basis of the satisfaction degree investigation and statistical analysis on the present situation of the library service in the new campus of the university, the paper made the study on the demand of the paper resources in the new campus. Our results suggest that the scientific layout of literature resources and carry out mobile library services, extend the opening time, promote the "campus seat card "is to develop the new campus library "third places "function measures.
\end{abstract}

Keywords-new university campus; transitional library; the third place; literature resources

\section{INTRODUCTION}

Christian Mikunda first put forward the concept of the "third place" [1] in Austria in 2006, he believes that the first place is the family after the renovation, through the family decoration can express themselves. In 1960s, it was thought that the working environment with aesthetic interest was "the second place", because it had the power of inspiration. In 1980s, carefully designed shops and restaurants because of their comfort and habitability make people feel that this semi public place is the personal living space and become the third. Now, the "third place" refers to the other places frequented by the people in addition to the family and the office [2], it can be a street or in a favorite book, love music, even online BBS forum. In this paper, "third place" refers to the frequented environment and places in the new campus of the University in addition to the classroom (equivalent to the office), as well as dormitories and canteens (equivalent to the home) for the teachers and students.

Since 1990s, China began a large-scale university enrollment, the original campus is too small to meet the needs of college teachers and students to learn and live ,many colleges and universities begin to build the new campus, the new campus generally choose the picturesque scenery suburbs to avoid the crowded city. The new campus has broad campus and fresh air but also appeared some issues such as the lack of material and cultural life for the teachers and students. The library are considered as the third space different from family space, work space has become the consensus [3], and the new campus library landmark building, rich collection resources, leisure and pleasant environment is the ideal "third place " for the teachers and students. However, because the new campus library is the campus "landmark" to strengthen the campus culture positioning taste and rich cultural landscape [4], it is often built behind the new campus in the years because of the design, funding and other factors [5]. In order to meet the needs of the new campus literature information of teachers and students, colleges and universities set up the transitional Library before the new library have completed and put into use, but the transition library service satisfaction is low, unable to assume the "third place" function of the new campus .

\section{THE PRESENT SITUATION OF THE NEW CAMPUS TRANSITION LIBRARY AND INVESTIGATION OF STUDENTS' DEMAND FOR PAPER RESOURCES}

\section{A. Status Analysis}

In order to get the new campus of university library service status of the transition, the new campus of Yangtze University Wuhan campus 386 students elective course of document information retrieval was carried out to investigate the transition of library service satisfaction for two weeks, the surveyed students from the new campus of the different departments and professional schools, the number of the total number of students $8.04 \%$. In the survey, the boys accounted for $48 \%$, female students accounted for $52 \%$, undergraduate students accounted for $87 \%$, graduate students accounted for $13 \%$; concentrated in the ages of $20 \sim 26$. In addition to the above questionnaire survey, the author also organized two groups to discuss in order to complete the follow-up investigation. The results of the survey are shown in figure 1.

As in figure 1, the new campus of the transition of library staff satisfaction is $76 \%$, and the paper resources satisfaction is $25 \%$, self-study room satisfaction is $23 \%$, the satisfaction of electronic resources is $19 \%$, the opening time of the lowest satisfaction, only $14 \%$. From the above findings, the panelists discussed that the paper resources low satisfaction is mainly because the transition library area is small, can only provide simple books borrowing and reading service, teachers and students reflect the literature resources too little, configuration 
is not reasonable, some of the book nobody read, want to read the book often borrow. In terms of electronic resources, the transition library is only equipped with a small electronic reading room, electronic reading room seats lead to limited use of electronic resources. Many teachers and students' dissatisfactions focus on too little opened study-room, too few seat ,too short open time, and often close on holidays and etc.

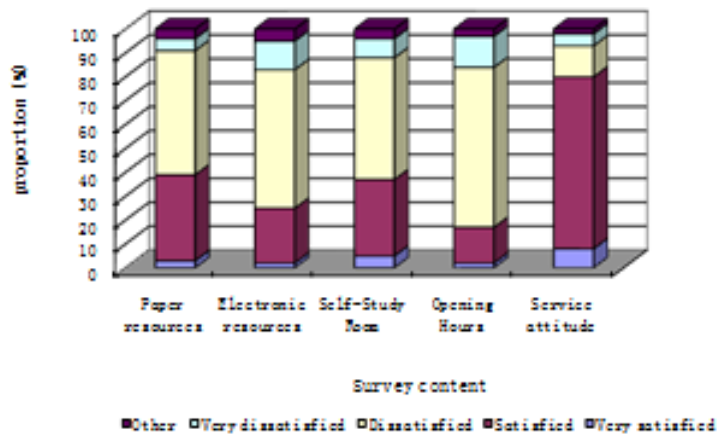

Fig. 1. Survey on the satisfaction of transition Library Service

\section{B. Investigation on the Demand of Paper Resources in New Campus}

The reasonable and scientific layout of the document resources is the basic guarantee for the library to carry out the document information service [6]. As the area of the transition library in new campus is small, based on the transition Library satisfaction analysis we made a survey paper resources demand of new campus, including books, periodicals and newspapers so that the limited space in the transition library is used reasonable. Since the information needs in different stage from each students are various, each kind of resources depends on 1 2 grade 3 4 grade and the graduates.

The investigation of electronic resources is not in the list because of its characteristic. The results are shown in figure 2 , figure 3 and figure 4.

According to results in figure 2 and figure 3 , the information resources demands for professional and academic in grades 1 2 on books and journals are less, the main reason is that the students in grade 1 2 have few professional course, but their literature demand for foreign language test is large, because they need pass the college English test (CET4\&CET6). However the professional and academic demand for the students in grade 3-4 increase significantly as they begin to learn the professional courses and write papers and feel the pressure to find jobs. The graduate students pay more attention to the professional literature. In addition, according to figure 2 , figure 3 , figure 4 , regardless of undergraduate or graduate students, humanities, social sciences, foreign languages, computer literature resources are the focus of their reading during the school, the variety and quantity of demand is larger.

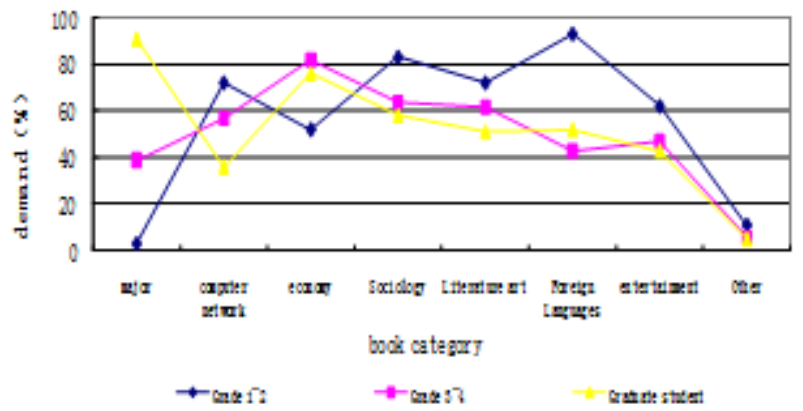

Fig. 2. Survey of book resources demand

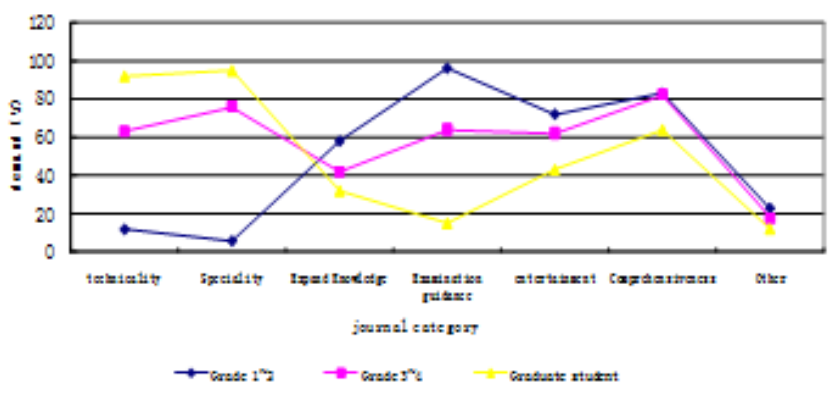

Fig. 3. Survey of journal resources demand

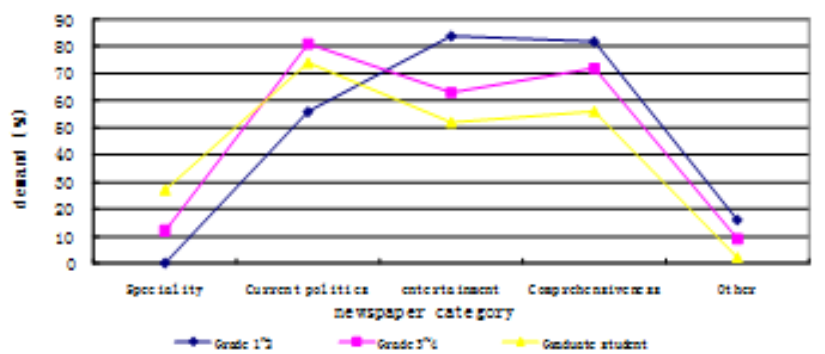

Fig. 4. Survey of newspaper resources demand

\section{PROPOSAL FOR DEVELOPMENT OF THE "THIRD PLACES" FUNCTION OF THE TRANSITIONAL LIBRARY IN THE NEW CAMPUS}

\section{A. Scientific layout and management of literature resources}

Based on analysis on the information resources demand of teachers and students in the new campus, we proposal that literature resources configuration should refer to the new campus teachers and students' information demand investigation before purchasing, in addition to professional books, teaching and research reference books, electronic resources and other professional literature .Meanwhile the faculties of the academic leaders and teachers reporting, other settled the students of grade category, the collection area, the transition of library after the completion of the new museum library, library relocation funds and a series of problems should be taken into account. In addition, the need to consider the particularity of the new campus, the appropriate increase in novel, economy and other types of collections, entertainment, and comprehensive journal newspaper can also add some. 
Because this kind of literature resources can be made up to a certain extent, the transitional library can make up for the cultural and recreational needs of the teachers and students in the remote campus. The books for student examination can not be much due to their strong timeliness, non collectible value and the future relocation issue. To Guide students to use as more the databases and electronic resources as possible purchased by college are strongly suggested.

\section{B. Developing Mobile Library Services}

According to "the thirty-eighth Chinese Internet development statistics report" released by CNNIC, till June 2016, China's netizens reached 710 million, 656 million mobile phone users, users of the students accounted for the highest, $25.1 \%$ [7]. Due to the characteristics of mobile learning personalized learning scene, mobile devices touch, voice output and other functional advantages, mobile education has become the mainstream of online education. To carry out mobile library services, teachers and students of the new campus can not be limited by time and place, and realize the sharing of the digital resources in the school library by means of handheld devices. New campus library building area is small, due to the transition of electronic reading room in the Library Electronic Resources limited, development of mobile library services can effectively compensate for the electronic resources service, but also make the future of the mobile library service test run. The mobile library generally have the following functions: Notice, the information of new books, popular books, reader recommendation, information retrieval, query, borrow, and renew books and read online library to buy electronic books, newspapers and periodicals in foreign language, video, you can also use the access to library document delivery did not buy the literature resources etc. In order to avoid the teachers and students mobile phone charges and traffic problems caused by the use of mobile library services, the need to achieve the library WIFI coverage.

\section{Inceasing the Opening Time}

The short opening time of the new campus is the lowest one of satisfaction degree of the library satisfaction survey. The teachers and students in the new campus hope to extend the opening hours of the transitional library. However, since the new library has not yet completed, the library staff is limited, only to meet the daily routine of open library. It is an effective measure to train the student assistant librarian to make up for the lack of the staff in the library. Foreign research results show that the number of students using the work reached $28.86 \%$ of the total number of library staff in the United States University Library [8]. Tsinghua University, Zhejiang University and other students will also be trained to become an important force in the construction of their library. In the use of student assistants, to strengthen the selection and management of the student assistants, and pay attention to the students' school and consider the students' course time in scheduling, only for the day's work in the early training, guided by the teacher after the selection of familiar business experience, strong sense of responsibility of the students to participate in the evening, on weekends or holidays. The entrance of the student assistant librarian will undoubtedly extend the opening hours of the library, so that more and more teachers and students can enter the library, use the library, and rely on the library to become the "third place"".

\section{Promote the "campus seat card"}

The college library study room is the place the students the most willing to patronize because the library study room has more academic atmosphere and study hard atmosphere, and provide drinking water, air conditioning compared to the dormitory and classroom, where can be not only quiet to learn and to think, can also are good to exchange and discuss, read books and newspapers, and free wireless internet access etc. which is really the "third place" that can make people relax and spiritual transition. However, due to the transition of library area is small, so compared to the official library study room, fewer seats scarcer, often hard to find a seat. Recently, many colleges and universities in the self-study room to promote the campus seat card". The "campus card seat" let the students need a seat sharing this time seat without worrying about his seat being taken. If one student leave the study room short ,he will write left time on his card, The promotion of the use of "campus seat card" in the transition library can make the transition library self-study room limited seats to be shared, so that its public resources to be more fully utilized.

\section{CONCLUSION}

In addition to work and home in modern society, there are a lot of other options, such as parks, cinemas, cafes, gym and so on, in fact, the real meaning of" third place", is a kind of people's spiritual life, is different from the work and family indispensable third normal life. The new campus remote strange environment, lack of material and cultural life of college students with a strong thirst for knowledge, vision and confusion about the future research is often not coordinated adaptation, college students in the tense, busy learning, eager to understand and communicate the need for a release of stress "third place ". If the effective measures are taken according to the existing conditions, the function of the "third places" of the new campus transitional library can be developed to a certain extent. At the same time, the new campus library is both big and small, whether formal or transition should be working to make it stop to attract new campus teachers and students of the "third place", let them find their spiritual knowledge and belong to here.

\section{REFERENCES}

[1] Christian Mikunda. Zhou et al. New experience and creative marketing. Beijing: Oriental Press, first edition, October 2006, pp. 2--12.In Chinese.

[2] Song Lin. Development and application of the "third place" function of University Library [J]. library work and study, 2012 (4).In Chinese.

[3] Bao Yongchan. Library: the city's "third space" [J]. library tribune, 2011 (5).In Chinese.

[4] Zheng Daixia. Orientation and service of new university library [J]. Research on library science, 2005(4).In Chinese.

[5] Chinese educational equipment network. [University library built 3 years is still a shell .The library built lag phenomenon generally].[ 201310-14].

http://www.ceiea.com/html/201310/201310141525062554.shtml.In Chinese. 
[6] Jia Yuqun, Li Guixiang et al. The layout and management of University Library's literature resources in multi campus mode [J]. information science, 2009 (3): 365-368.In Chinese.

[7] CNNIC released the thirty-eighth "development China statistical report on Internet". [China Internet Network Information Center].[2016-08-03]. http://www.cnnic.cn/gywm/xwzx/rdxw/2016/201608/t20160803_54389 htm.In Chinese.

[8] $\mathrm{Lu}$ Yaqi. Introduction and Enlightenment of student assistant management in University of Maryland Library. [J]. library tribune, 2010 (5).In Chinese 